\title{
State-of-the-art and perspectives in the heavy mineral industry of Sri Lanka
}

\author{
H. C. S. Subasinghe ${ }^{1} \cdot$ Amila Sandaruwan Ratnayake $^{1}$ (I) $\cdot$ K. A. G. Sameera ${ }^{2}$
}

Received: 18 March 2021 / Accepted: 6 June 2021 / Published online: 15 June 2021

(C) The Author(s), under exclusive licence to Springer-Verlag GmbH Germany, part of Springer Nature 2021

\begin{abstract}
Heavy minerals have become an essential commodity in modern-day technology. The objective of this study is to examine the current status of the heavy mineral industry of Sri Lanka. The present study also examines the economic viability of potential heavy mineral placer deposits, based on geochemical data. Field investigations suggested the occurrence of heavy minerals as beach-placers, and inland/raised beach deposits along the coastline of Sri Lanka. Geochemical results showed the enrichment of $\mathrm{TiO}_{2}, \mathrm{Fe}_{2} \mathrm{O}_{3}, \mathrm{Al}_{2} \mathrm{O}_{3}$, and trace elements, and depletion of other major oxides such as $\mathrm{Na}_{2} \mathrm{O}, \mathrm{K}_{2} \mathrm{O}, \mathrm{MnO}, \mathrm{MgO}, \mathrm{CaO}$, and $\mathrm{P}_{2} \mathrm{O}_{5}$. Consequently, it suggests the abundance of ilmenite, leucoxene, rutile, sillimanite, garnet, and rare earth element (REE)-bearing heavy minerals in potential placer deposits. In contrast, this study illustrates the exported quantity (in the weight ratio of 35:3:1) of ilmenite, rutile, and zircon minerals during the last decade. Ilmenite is the dominant heavy mineral in Sri Lanka, and thus, its production and price volatilisations are essential to understand the current status and predict the future behaviour of the heavy mineral industry. Statistical observations suggest that the global production and unit price variations of ilmenite have increased gradually from 1950 to 2015. Besides, the forecasted variations in annual global production and unit price changes of ilmenite indicate healthy compound annual growth rates of $1.27 \%$ and $1.43 \%$, respectively. However, Sri Lanka has less contribution $(<$ $1 \%)$ to global ilmenite production. Consequently, the value addition of ilmenite must be highly encouraged with at least an immediate stage (e.g. synthetic rutile). The present study also highlights possible value addition stages of available heavy mineral resources (low-, intermediate-, or high-level value addition), and discusses action plans to improve the quality of the heavy mineral industry of Sri Lanka. In recommendations, imposing sustainable regulations and policies would uplift the heavy mineral industry of Sri Lanka. For example, value addition to local heavy minerals and terminating raw commodity export are highly recommended.
\end{abstract}

Keywords Heavy minerals · Sri Lanka · Value addition · Sustainable utilisation

\section{Introduction}

Heavy minerals can be defined as (i) having density greater than common rock-forming minerals such as quartz with a density of $2.65 \mathrm{~g} / \mathrm{cm}^{3}$ (Elsner 2010), (ii) clastic grains having specific gravities greater than 2.9 $\mathrm{g} / \mathrm{cm}^{3}$ (USGS 2021), and (iii) minerals having densities

Amila Sandaruwan Ratnayake

as_ratnayake@uwu.ac.lk

1 Department of Applied Earth Sciences, Faculty of Applied Sciences, Uva Wellassa University, Passara Road, Badulla 90000, Sri Lanka

2 Geological Survey and Mines Bureau, 569, Epitamulla Road, Pitakotte, Sri Jayawardenepura Kotte, Sri Lanka greater than $3.0 \mathrm{~g} / \mathrm{cm}^{3}$ (IAEA 2007). Nevertheless, there is still no standard scientific or industry definition for heavy minerals (Perks and Mudd 2019). These heavy minerals are interested in many high-end applications such as pigments, tiles, ceramics, paints, refractory materials, commercial aerospace, nuclear reactors, photovoltaic cells, nanotechnology, electronics, and many other cutting-edge applications (Dushyantha et al. 2020; Elsner 2010; Perks and Mudd 2019). Ilmenite $(\mathrm{FeOTiO} 2)$, rutile $\left(\mathrm{TiO}_{2}\right)$, leucoxene (altered ilmenite), zircon $\left(\mathrm{ZrSiO}_{4}\right)$, monazite $\left((\mathrm{Ce}, \mathrm{La}, \mathrm{Nd}, \mathrm{Th}) \mathrm{PO}_{4}\right)$, garnet $\left((\mathrm{Ca}, \mathrm{Mg}, \mathrm{Fe}, \mathrm{Mn})_{3}(\mathrm{Al}, \mathrm{Fe}, \mathrm{Mn}, \mathrm{V}, \mathrm{Cr})_{2}\left(\mathrm{SiO}_{4}\right)_{3}\right)$, and sillimanite $\left(\mathrm{Al}_{2} \mathrm{SiO}_{5}\right)$ can be recognised as common minerals in the heavy mineral industry (Perks and Mudd 2019, 2020, 2021). Heavy mineral deposits are located in around 45 countries, prominently along the coastlines neighbouring the Indian Ocean 
(e.g. Australia, Asia, and Africa). Minerals bearing titanium, zirconium, and rare earth elements (REEs) have diversified applications in modern industries, and thus, these minerals have dominated the global mineral market (Jowitt et al. 2020; Mudd 2020). Consequently, the demand for ilmenite, rutile, zircon, and REE-bearing mineral sands has gradually increased over the last few decades in the global heavy mineral market. Interestingly, these minerals are found in two types of deposits typically classified as primary and secondary. The primary deposits are formed via magmatic, hydrothermal, and metamorphic processes whilst the secondary deposits are formed by weathering, erosion, and transportation (Dushyantha et al. 2020; Skinner and Barton 1973; Zahid and Barbeau 2010; Zhong et al. 2016). However, only a few hard rock deposits such as Russia's Kovdor baddeleyite-apatite-magnetite deposit (zirconium mine, as a by-product) and Canada's Lac Tio, Norway's Tellnes, and China's Damiao deposits (titanium mines) are currently being operated (Perks and Mudd 2019, 2020, 2021). Moreover, large-scale secondary deposits such as those found in Sri Lanka are economically mineable than most of the primary deposits, apart from technical, political, and environmental considerations (Perks and Mudd 2020, 2021).

Although Sri Lanka is globally famed for the occurrence of high-grade heavy mineral deposits (e.g. Pulmoddai), the minerals exploited are not properly beneficiated in terms of value addition. Moreover, heavy minerals are exported in their raw form with only a fundamental value addition (i.e., separation). For example, the tonnages of raw ilmenite, rutile, zircon, and hi-titanium ilmenite exported in the year 2019 are 17704, 3173, 1270, and 16645, respectively (Unpublished data, Lanka Mineral Sands Limited Sri Lanka). Moreover, there are no records of the production and export of value-added products from Sri Lankan heavy minerals. This implies that the downstream heavy mineral industry of Sri Lanka is extremely weak, and it is really disadvantageous for the economy of the country. Consequently, the downfalls of rules and regulations must be duly examined along with political roadblocks such as the lack of long-term rules and plans for uplifting the heavy mineral industry of Sri Lanka. For example, the last cabinet paper on "Mining and Export of Mineral Sands" was issued in 2012 by the government of Sri Lanka. The term value addition stated in this cabinet paper has not been properly implemented in the mineral industry. Therefore, formulating timely required perceptions would really benefit the downstream heavy mineral industry of Sri Lanka. In contrast, the decreasing primary resource quantity has been identified as a common issue in the mineral industry (Humphreys 2020). Consequently, the exploration of potential heavy minerals deposits (i.e., resource availability) also plays a key role in the sustainability of the heavy mineral industry.

The current status of the heavy mineral industry and its perspectives are poorly examined in Sri Lanka. Therefore, this paper presents and assesses the heavy mineral industry of Sri Lanka related to ilmenite, rutile, and zircon using real-time data, obtained from Lanka Mineral Sands Limited (LMSL), during the last decade. The work figured out in this paper would be the first assessment comparing the Sri Lankan heavy mineral industry with the global industry using United States Geological Survey (USGS) data. In addition, this study aims to discuss the present status, existing drawbacks, challenges, and recommendations for uplifting the downstream heavy mineral industry of Sri Lanka, based on mineral market analysis. Consequently, this article shares perspectives/new concepts on economic, legal, and political implications to enhance the future downstream heavy mineral industry of Sri Lanka. Furthermore, this study focusses to identify resource availability for maintaining a sustainable upstream heavy mineral industry in Sri Lanka.

\section{Methodology}

\section{Feasibility and economic potential of heavy mineral placers}

Extensive field excursions were carried out to identify the feasibility and economic potential of heavy mineral placers in Sri Lanka. Sediment samples were collected from these potential placers, including the coastline, and raised beaches. Representative sediment samples were obtained from 10 locations (Aruwakkalu, Beruwala, Kalutara, Dharga Town, Kaikawala, Kosgoda, Payagala, Dikwella, Verugal, and Pulmoddai) covering the entire coastline of Sri Lanka. Samples were collected from the berm by removing the surficial materials. Major and trace element compositions of beach and raised beach sediments were measured using X-ray fluorescence (XRF) analysis. The oven-dried $\left(>24 \mathrm{~h}\right.$ at $\left.110^{\circ} \mathrm{C}\right)$ beach sediments were crushed, and total loss on ignition (LOI) was determined by ignition in a muffle furnace for about $3 \mathrm{~h}$ at $1000^{\circ} \mathrm{C}$. The ignited powders of beach sediments $(9.00 \mathrm{~g})$ and grinding pellets as a binder $(2.70 \mathrm{~g})$ were mixed in an agate motor. These mixtures were used to prepare $40-\mathrm{mm}$ diameter pellets by compression method. These pellets were analysed using the GEO-QUANT T analytical suite and an S8-Tiger Wavelength Dispersive XRF spectrometer.

\section{Pre-existing data analysis/mineral market analysis}

The available data of Lanka Mineral Sands Limited (LMSL) were used to identify temporal variations of exported quantity and sales values of common heavy mineral commodities (i.e. ilmenite, rutile, and zircon) in Sri Lanka. These observations were used to interpret the current status of the heavy mineral industry of Sri Lanka. Next, the amounts of ilmenite exported from Sri Lanka from 1994 up to 2015 and the global production of ilmenite were tabulated using raw data from the Mineral Year Books of the United States Geological Survey 
(USGS 2021), for determining Sri Lanka's contribution to the global heavy mineral industry.

The annual global production and unit price variations of ilmenite, identified as the dominant heavy mineral in Sri Lanka, were analysed using data of the Mineral Year Books of the United States Geological Survey (USGS 2021). A period of 6.5 decades from 1950 to 2015 was considered during this analysis. After that, the production and unit price variations of ilmenite were forecasted for a period of 15 years by a time series decomposition analysis using Minitab17 statistical software.

\section{Results and discussion}

\section{Potential heavy mineral resource availability}

The current study examined potential heavy mineral placer deposits in Sri Lanka (Fig. 1). Heavy mineral placers are found to occur mainly along the northeast coastline of Sri Lanka such as Pulmoddai, Mulativu, Nayaru, Vakarei, Verugal, and Thirukkovil (Fig. 1). Almost all of these deposits are mainly composed of ilmenite, and exploitable amounts of leucoxene, rutile, garnet, monazite, zircon, and sillimanite as well as minor amounts of magnetite (Amalan et al. 2018).
Interestingly, these deposits are naturally conserved due to annual partial replenishment during the northeast monsoon. In addition, locations in the southern coastline such as Dondra, Dikwella, Ambalantota, Godawaya (mainly garnet), and Kirinda (both garnet and ilmenite) have been identified to stand heavy minerals (Fig. 1). Apart from these, certain locations in Kalpitiya and Mannar in the northwest coastline of Sri Lanka have been identified as potential areas for heavy mineral placer deposits (Fig. 1). The ongoing feasibility study reported an average of 3-5\% of heavy minerals, rarely exceeding $10 \%$ only at certain locations along the northwest coastline of Sri Lanka (Unpublished data, Geological Survey and Mines Bureau Sri Lanka). Furthermore, the proper quantification is required to determine the exploitation potential of heavy mineral placers in beach (e.g. Beruwala and Kalutara) and raised beach/paleo-placer (e.g. Kosgoda, Payagala, Dharga Town, Kaikawala) areas along the western coast of Sri Lanka (Fig. 1). Moreover, reservoir estimation (extended area, depth, and grade) and feasibility of their exploration are yet to be determined. However, the authors investigated geochemistry of these heavy mineral placers for qualitative assessment (Fig. 2).

$\mathrm{SiO}_{2}$ contents of Verugal, Aruwakkalu, Kosgoda, Dharga Town, Kalutara, and Beruwala are $74.76 \%, 72.15 \%, 43.59 \%$, $45.07 \%, 59.80 \%$, and $55.50 \%$, respectively (Fig. 2). These
Fig. 1 Simplified geological map of Sri Lanka shows the identified heavy mineral resource availability

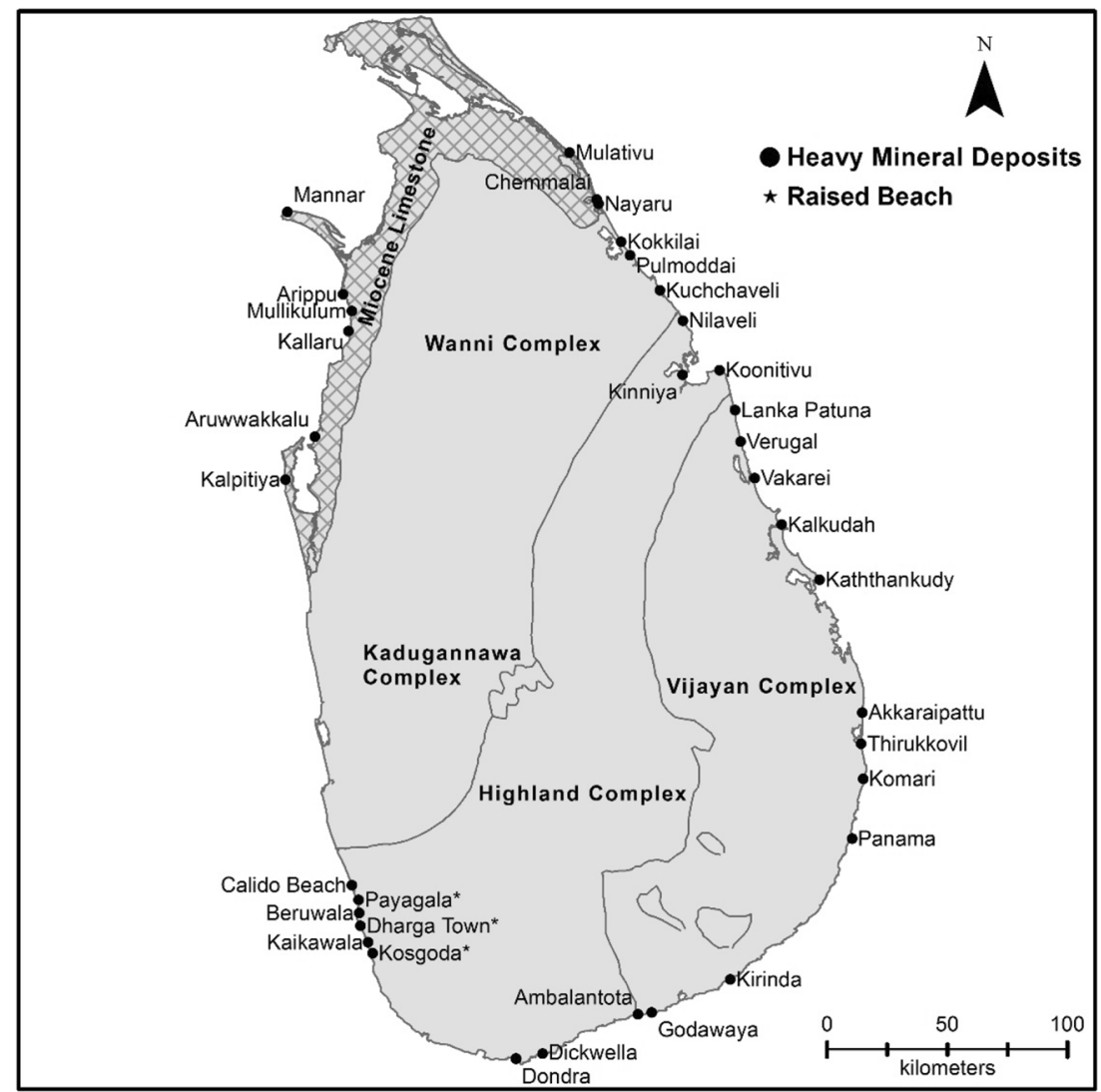



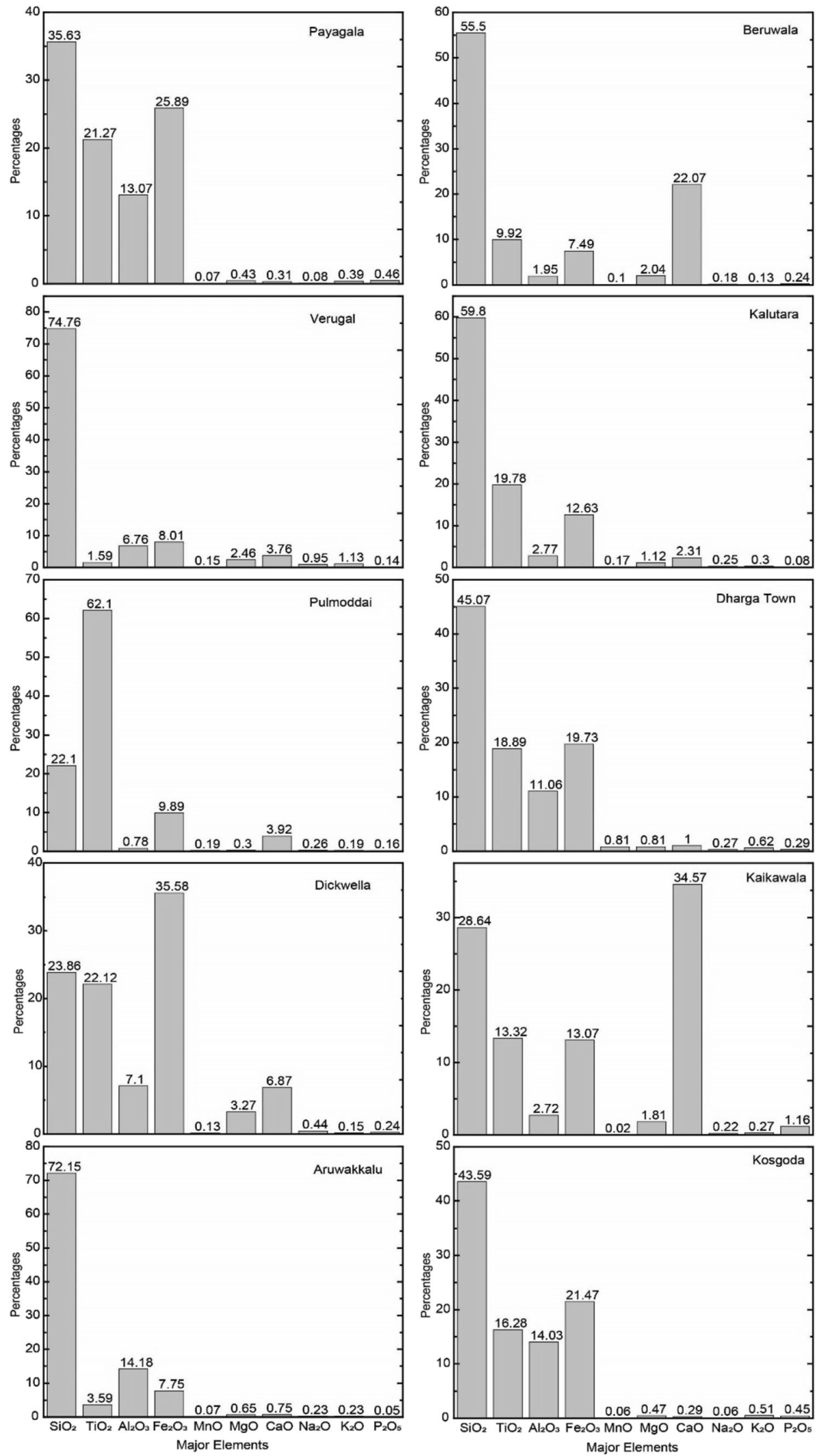

Fig. 2 Variations of average major element percentages in sampling locations 
values are high compared to $\mathrm{SiO}_{2}$ contents of Payagala (36.63\%), Pulmoddai $(22.10 \%)$, Dikwella (23.86\%), and Kaikawala (28.64\%) placer deposits (Table 1 and Fig. 2). Higher percentages of major elements such as $\mathrm{TiO}_{2}$, $\mathrm{Fe}_{2} \mathrm{O}_{3}$, and $\mathrm{Al}_{2} \mathrm{O}_{3}$ indicate the presence of heavy minerals. Besides, the $\mathrm{TiO}_{2}$ content is over $10 \%$ in all the locations except Aruwakkalu, Verugal, and Beruwala (Fig. 2). In contrast, the $\mathrm{Fe}_{2} \mathrm{O}_{3}$ values are also higher than $10 \%$ in all the sampled locations except Aruwakkalu, Pulmoddai, Verugal, and Beruwala (Table 1 and Fig. 2). In addition, the $\mathrm{Al}_{2} \mathrm{O}_{3}$ contents of Verugal, Pulmoddai, Dikwella, Kaikawala, Kalutara, and Beruwala are lower than $10 \%$ compared to the other locations (Table 1 and Fig. 2). These three major elements indicate the abundance of titanium-bearing heavy minerals such as ilmenite, leucoxene, and rutile, and the presence of aluminium-rich minerals such as sillimanite and garnet in the sampled locations. Other major oxides such as $\mathrm{Na}_{2} \mathrm{O}, \mathrm{K}_{2} \mathrm{O}, \mathrm{MnO}$, $\mathrm{MgO}, \mathrm{CaO}$, and $\mathrm{P}_{2} \mathrm{O}_{5}$ are clearly depleted in these analysed samples (Table 1 and Fig. 2).

The abundance of trace elements such as $\mathrm{La}, \mathrm{Ce}, \mathrm{Nb}, \mathrm{Zr}$, and Th indicates the presence of REE-bearing heavy minerals such as monazite and zircon in the sampled locations (Table 1 and Fig. 3). Interestingly, samples from each location showed enriched zirconium $(\mathrm{Zr})$ contents potentially due to higher concentrations of zircon mineral (Table 1 and Fig. 3). Therefore, all these locations can be identified as prospective heavy mineral deposits. Proper grade and volumetric estimations need to be considered for determining the feasibility of future exploitation.

Table 1 Whole-rock major and trace element compositions of modern and paleo beach placers, and Aruwakkalu, Sri Lanka. The average upper continental crust (UCC) values were obtained after Rudnick and Gao (2005)

Sample Beruwala Kalutara Dharga Town Kaikawala Kosgoda Payagala Verugal Pulmoddai Dickwella Aruwakkalu UCC

Rudnick and Gao (2005)

\begin{tabular}{|c|c|c|c|c|c|c|c|c|c|c|c|}
\hline \multicolumn{12}{|c|}{ Major elements (wt\%) } \\
\hline $\mathrm{SiO}_{2}$ & 55.50 & 59.80 & 45.07 & 28.64 & 43.59 & 35.63 & 74.76 & 22.10 & 23.86 & 72.15 & 66.60 \\
\hline $\mathrm{TiO}_{2}$ & 9.92 & 19.78 & 18.89 & 13.32 & 16.28 & 21.27 & 1.59 & 62.10 & 22.12 & 3.59 & 0.64 \\
\hline $\mathrm{Al}_{2} \mathrm{O}_{3}$ & 1.95 & 2.77 & 11.06 & 2.72 & 14.03 & 13.07 & 6.76 & 0.78 & 7.10 & 14.18 & 15.40 \\
\hline $\mathrm{Fe}_{2} \mathrm{O}_{3}$ & 7.49 & 12.63 & 19.73 & 13.07 & 21.47 & 25.89 & 8.01 & 9.89 & 35.58 & 7.75 & 5.04 \\
\hline $\mathrm{MnO}$ & 0.10 & 0.17 & 0.81 & 0.02 & 0.06 & 0.07 & 0.15 & 0.19 & 0.13 & 0.07 & 0.10 \\
\hline $\mathrm{MgO}$ & 2.04 & 1.12 & 0.81 & 1.81 & 0.47 & 0.43 & 2.46 & 0.30 & 3.27 & 0.65 & 2.48 \\
\hline $\mathrm{CaO}$ & 22.07 & 2.31 & 1 & 34.57 & 0.29 & 0.31 & 3.76 & 3.92 & 6.87 & 0.75 & 3.59 \\
\hline $\mathrm{Na}_{2} \mathrm{O}$ & 0.18 & 0.25 & 0.27 & 0.22 & 0.06 & 0.08 & 0.95 & 0.26 & 0.44 & 0.23 & 3.27 \\
\hline $\mathrm{K}_{2} \mathrm{O}$ & 0.13 & 0.30 & 0.62 & 0.27 & 0.51 & 0.39 & 1.13 & 0.19 & 0.15 & 0.23 & 2.80 \\
\hline $\mathrm{P}_{2} \mathrm{O}_{5}$ & 0.24 & 0.08 & 0.29 & 1.16 & 0.45 & 0.46 & 0.14 & 0.16 & 0.24 & 0.05 & 0.15 \\
\hline \multicolumn{12}{|c|}{ Trace elements (ppm) } \\
\hline $\mathrm{Ba}$ & 2 & 2 & 2 & 2 & 2 & 2 & 303 & 2 & 2 & 11 & 628 \\
\hline $\mathrm{Ce}$ & 1075 & 411 & 5647 & 10,302 & 3893 & 5620 & 60 & 981 & 1503 & 161 & 63 \\
\hline $\mathrm{Cr}$ & 286 & 311 & 256 & 123 & 167 & 275 & 344 & 330 & 250 & 87 & 92 \\
\hline $\mathrm{Ga}$ & 20 & 21 & 15 & 4 & 21 & 14 & 18 & 4 & 4 & 16 & 18 \\
\hline $\mathrm{Nb}$ & 299 & 161 & 678 & 536 & 576 & 475 & 24 & 699 & 650 & 68 & 12 \\
\hline $\mathrm{Ni}$ & 17 & 24 & 55 & 30 & 43 & 35 & 41 & 16 & 49 & 29 & 47 \\
\hline $\mathrm{Pb}$ & 61 & 23 & 236 & 227 & 223 & 143 & 11 & 96 & 125 & 31 & 17 \\
\hline $\mathrm{Rb}$ & 9 & 11 & 0 & 0 & 0 & 3 & 23 & 83 & 28 & 22 & 84 \\
\hline $\mathrm{Sr}$ & 1141 & 78 & 12 & 2779 & 16 & 16 & 129 & 108 & 479 & 22 & 320 \\
\hline $\mathrm{Th}$ & 502 & 135 & 3794 & 4643 & 2852 & 2217 & 3 & 441 & 1150 & 62 & 11 \\
\hline $\mathrm{V}$ & 303 & 402 & 700 & 477 & 539 & 680 & 145 & 1197 & 756 & 167 & 97 \\
\hline $\mathrm{Y}$ & 38 & 69 & 114 & 131 & 104 & 71 & 41 & 5 & 86 & 15 & 21 \\
\hline $\mathrm{Zr}$ & 8943 & 1480 & 28,544 & 32,036 & 27,074 & 21,774 & 246 & 6547 & 45,052 & 1781 & 193 \\
\hline $\mathrm{La}$ & 622 & 160 & 2588 & 6051 & 1687 & 2606 & 16 & 445 & 708 & 52 & 31 \\
\hline As & 33 & 6 & 31 & 42 & 38 & 20 & 4 & 49 & 38 & 12 & 5 \\
\hline $\mathrm{Zn}$ & 180 & 321 & 134 & 66 & 163 & 198 & 96 & 234 & 200 & 46 & 67 \\
\hline $\mathrm{Cu}$ & 30 & 35 & 48 & 40 & 41 & 38 & 5 & 101 & 79 & 11 & 28 \\
\hline
\end{tabular}



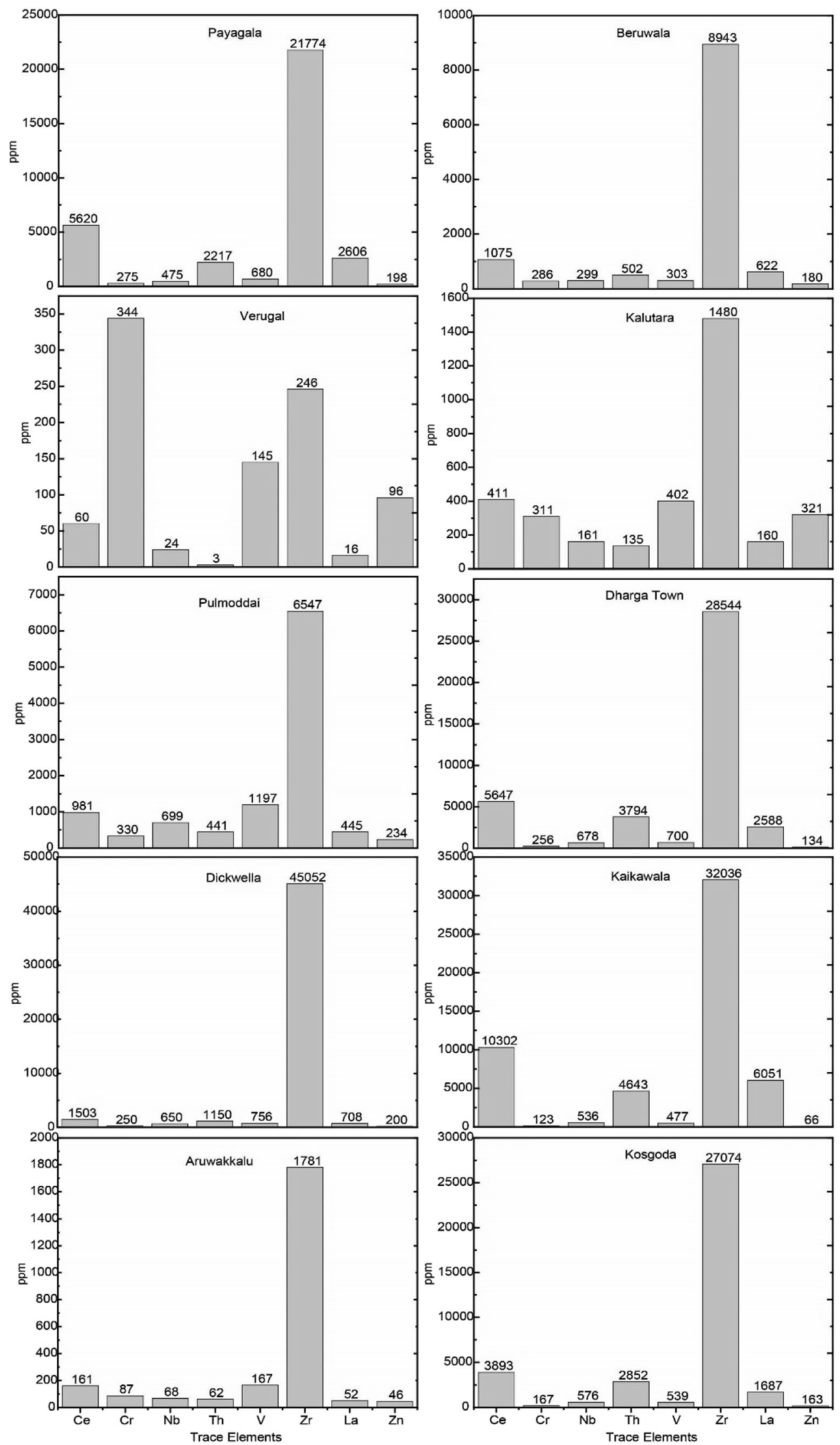

Fig. 3 Variations of average trace element percentages in sampling locations 
This study provides an opportunity to compare major and trace element compositions with the well-established commercial deposit of Pulmoddai. Figure 4 shows the degree of enrichment compared to the average upper continental crust (UCC) values after Rudnick and Gao (2005). The normalizations were made on an anhydrous normalised basis, excluding loss on ignition (Table 1). Notably, $\mathrm{TiO}_{2}$ and $\mathrm{Fe}_{2} \mathrm{O}_{3}$ are enriched relative to UCC values in all the prospective locations for heavy mineral placer deposits. Besides, $\mathrm{TiO}_{2}$ values are enriched at least by 10 -folds except for the location at Verugal (Fig. 4). It suggests that ilmenite $\left(\mathrm{FeOTiO}_{2}\right)$, leucoxene (a mixture of rutile and pseudorutile), and rutile $\left(\mathrm{TiO}_{2}\right)$ are dominant heavy minerals in coastal placer deposits of Sri Lanka (Fig. 4). Interestingly, $\mathrm{SiO}_{2}$ contents of almost all of these deposits are depleted in comparison to UCC values (Fig. 4). Consequently, the depletion of $\mathrm{SiO}_{2}$ indicates higher concentrations of heavy minerals in beach sediments. Trace elements such as $\mathrm{Zr}$, Th, $\mathrm{V}, \mathrm{La}, \mathrm{Ce}$, and $\mathrm{Nb}$ are also highly enriched compared to UCC values. Therefore, it suggests the presence of heavy minerals such as zircon $\left(\mathrm{ZrSiO}_{4}\right)$ and monazite ((Ce, $\left.\mathrm{La}, \mathrm{Nd}, \mathrm{Th}) \mathrm{PO}_{4}\right)$ in beach sediments (Fig. 4).

\section{Statistical analysis}

\section{Local scenario on the mineral market}

Figure 5 shows exported quantity of common heavy minerals in Sri Lanka during the last decade. Thousands of metric tonnes of heavy minerals have been exported in their raw forms (just after separation) since the beginning of heavy mineral mining at the Pulmoddai deposit in 1957 (Herath 1980). Ilmenite is the dominant heavy mineral commodity exported from Sri Lanka (Fig. 5). Table 2 shows the amount of ilmenite

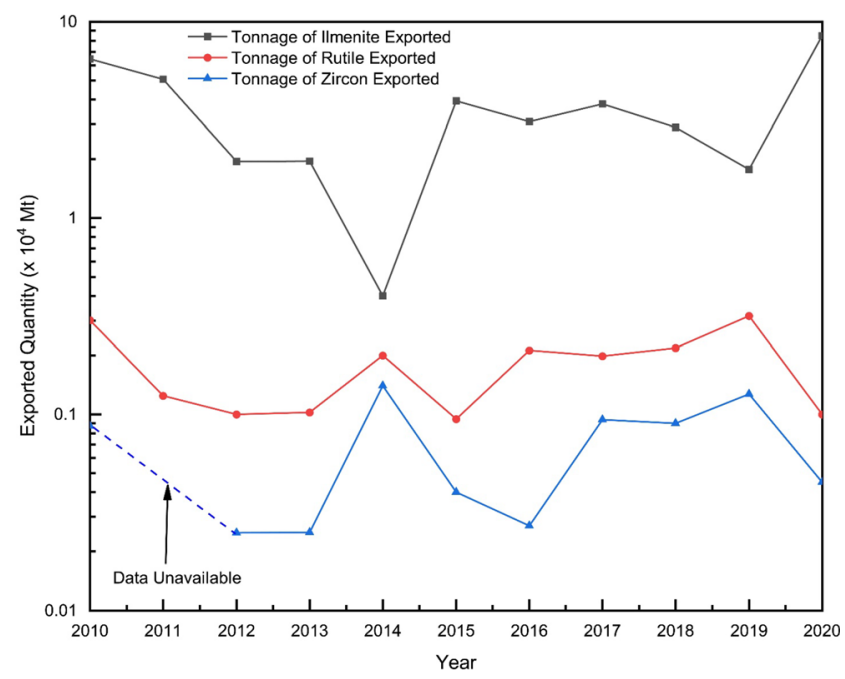

Fig. 5 Total amount of ilmenite, rutile, and zircon exported from Sri Lanka during the last decade (raw data from Lanka Mineral Sands Limited: LMSL)

exported from Sri Lanka and its global contribution. Sri Lanka's contribution is extremely low $(<1 \%)$ to the global heavy mineral market compared to other countries such as Australia, China, India, and South Africa (Table 2). Certainly, the current production capacity of Sri Lanka is low compared to leading heavy mineral suppliers to the international market, which is also evident with the export data of the LMSL and USGS database (Table 2). Consequently, adapting timely required regulatory measures and policies is required to enhance the economic benefits and sustainability of the heavy mineral industry of Sri Lanka. For example, exporting ilmenite in its raw form must be highly discouraged and terminated, introducing with at least an intermediate stage of value addition (e.g. conversion of ilmenite to synthetic
Fig. 4 UCC-normalised major and trace element variations of modern and paleo placers and the red soil overburden of Aruwakkalu, in Sri Lanka. All the elements are organised in the ascending order of normalised values (from left to right) in average Mesozoic-Cenozoic sandstone (after Condie 1993) relative to UCC (after Rudnick and Gao 2005). Major elements and trace elements are normalised as oxides and as ppm, respectively

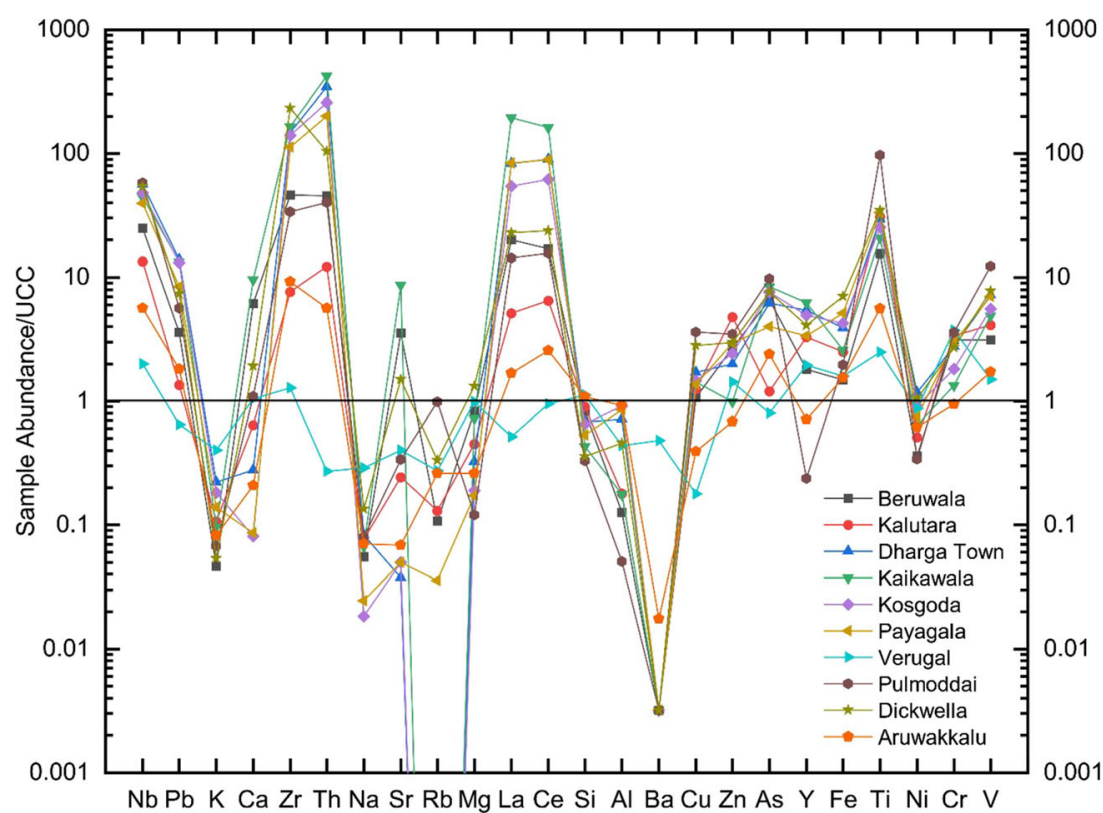


Table 2 Tonnage of ilmenite exported from Sri Lanka for a period from 1994 to 2015 (raw data from Lanka Mineral Sands Limited), and the percentage of ilmenite exported to the international ilmenite market

\begin{tabular}{llll}
\hline Year & Amount of Ilmenite exported (tonnes) & Global production & Sri Lanka's contribution (\%) \\
\hline 1994 & 32,000 & $3,970,000$ & 0.81 \\
1995 & 34,000 & $4,010,000$ & 0.85 \\
1996 & 33,000 & $4,010,000$ & 0.82 \\
1997 & 10,000 & $4,070,000$ & 0.25 \\
1998 & 16,000 & $4,560,000$ & 0.35 \\
N/A & $*$ & $*$ & \\
2009 & 11,000 & $5,440,000$ & 0.20 \\
2010 & 64,500 & $7,760,000$ & 0.83 \\
2011 & 50,800 & $7,290,000$ & 0.70 \\
2012 & 19,500 & $7,300,000$ & 0.28 \\
2013 & 19,500 & $7,640,000$ & 0.26 \\
2014 & 4000 & $7,350,000$ & 0.05 \\
2015 & 39,500 & $7,130,000$ & 0.55 \\
\hline
\end{tabular}

*Data unavailable in USGS mineral year books rutile). In this case, the compensation received from the heavy mineral industry can be raised by a factor of 8.0 or more (Fig. 6). Therefore, it is recommended to terminate the export of heavy minerals in their near raw form (low-level value addition) with immediate action and plans. Furthermore, it is essential to utilise these resources sustainably by extracting the maximum possible amounts of valuables with minimum environmental disturbance. The idea of environmental sustainability/minimum environmental disturbance is a challenging task, and it is associated with historical production trends and the relationship between resource magnitude and current production rate (Mudd 2010).

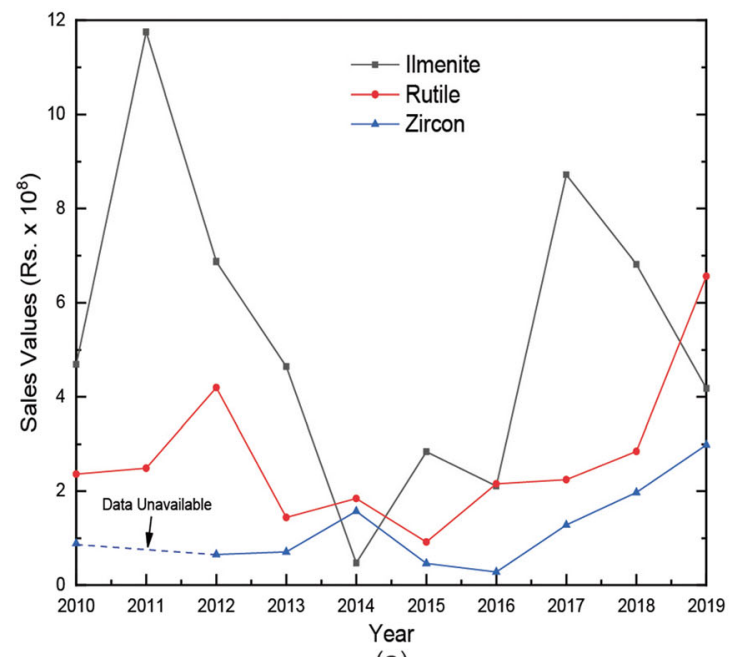

(a)

\section{Global scenario on the mineral market}

The authors examined the annual global production and unit price changes of ilmenite from 1950 to 2015 , and also forecasted variations from 2015 to 2030 . The global production and unit price changes of ilmenite have increased gradually (Fig. 7), due to the growth of global demand for titaniumbased materials. The titanium-based heavy mineral industry is thus drastically expanding with the increase of the global population. Therefore, identification of new mines, expansion of existing mines, reworking of abandoned mines (if feasible), and adoption of updated or new technology are timely

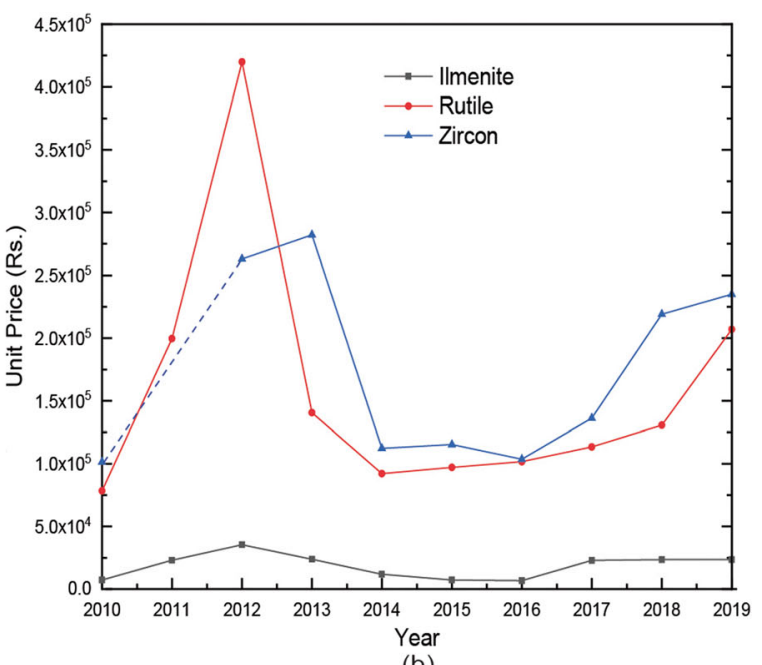

(b)

Fig. 6 a Total compensation received by the sales of ilmenite, rutile, and zircon during the last decade, and $\mathbf{b}$ the unit price of each heavy mineral commodity (raw data from Lanka Mineral Sands Limited: LMSL) 


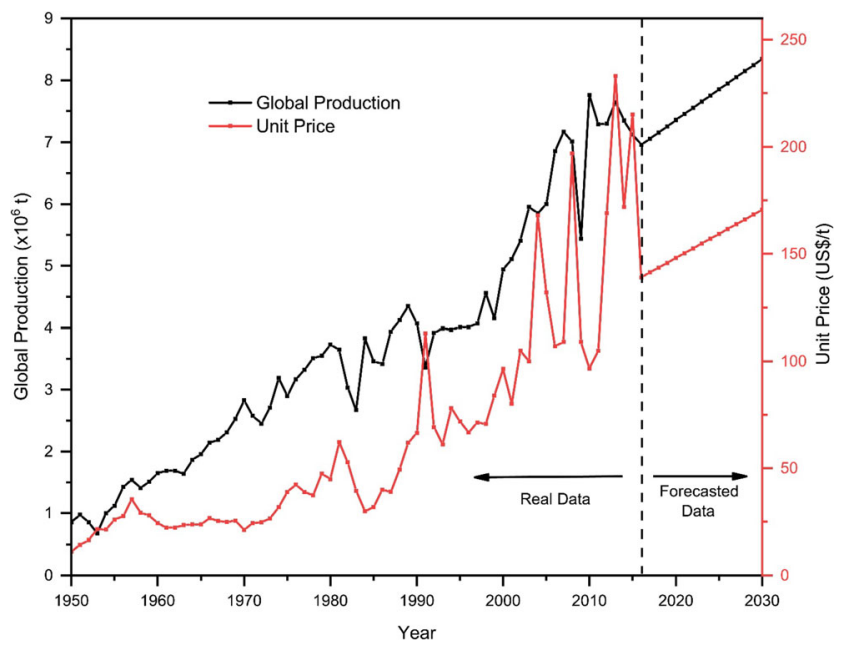

Fig. 7 Global annual production and price variations of ilmenite for a period of 65 years (raw data from Bureau of Mines and the U.S. Geological Survey Mineral Yearbooks, and the Mineral Commodity Summaries). Time-series decomposition analysis was carried out to forecast the global annual production and price variations of ilmenite until 2030 using Minitab 17 statistical software)

essentials to cover global requirements (Mudd 2010). The time series decomposition analysis shows weak seasonal changes for annual global production and unit price variations (Fig. 7). The estimations suggest that the compound annual growth rates (CAGRs) of global production and unit price of ilmenite are $1.27 \%$ and $1.43 \%$, respectively, over the forecast period of 2015-2030 (Fig. 7). However, these predictions were made considering no production and supply disruptions/bottlenecks (e.g. the COVID-19 global pandemic, extreme hazardous events) in the periods of forecasting.

\section{Perspectives}

\section{Value addition potential of heavy minerals}

Several investigations have been carried out to examine possible value-added products for heavy mineral commodities. For example, various feasible methods such as chemical, physical, and metallurgical processes have been found to produce synthetic rutile from ilmenite (Nguyen and Lee 2018; Wijewardhana et al. 2021; Zhang et al. 2011). The authors identified three potential stages for value addition of heavy mineral resources in Sri Lanka such as low-level value addition (e.g. separation of heavy minerals from raw sand), intermediate-level value addition (e.g. production of synthetic rutile from ilmenite), and high-level value addition (e.g. production of highquality white pigments from rutile). However, Sri Lankan heavy mineral industry has not been the focus of any intermediate- and high-level value addition on an industrial scale. Although it is highly competitive and challenging, ilmenite/leucoxene/hi-titanium ilmenite can be focused on the production of intermediate synthetic rutile and titanium sponge (Fig. 8), as titanium-bearing minerals are highly abundant along the coastline of Sri Lanka. Consequently, upgrading heavy minerals using methods described in Palliyaguru et al. (2017) and Wijewardhana et al. (2021) would be highly recommended to uplift the downstream heavy mineral industry of Sri Lanka. This also suggests a higher potential and a probability for Sri Lanka to get into the mineral processing industry. Furthermore, synthetic rutile produced from ilmenite feedstock, leucoxene, and natural rutile can be used as the feed material to produce high-grade titanium dioxide, pigments, and metal titanium (Nguyen and Lee 2018; Perks and Mudd 2020; Zhang et al. 2011).

Many of the heavy mineral placers in Sri Lanka are composed of considerable concentrations of zircon sand. Afterwards, zircon can be beneficially utilised to uplift the heavy mineral industry of the country. Sri Lanka is also famed for its high-quality ceramic products. Consequently, zircon can be used to enhance opaqueness, and heat, water, chemical, and abrasion resistance of high-quality ceramics, refractory, and foundry products (Fig. 8). Baddeleyite (zirconium dioxide- $\mathrm{ZrO}_{2}$, accessory mineral in mafic and silicaundersaturated plutonic rocks/dykes) is also found along with zircon in beach placers of Sri Lanka. Baddeleyite is mainly used for zircon metal, and the market is extremely opaque and small. However, it is not advisable to recommend Sri Lankan companies to get into zircon/baddeleyite milling industry, without a serious discussion on power prices and labour costs.

Garnet sands can be used in the production of advanced water filtration and abrasives (Elsner 2010; Muttashar et al. 2018). Sillimanite and monazite are available in mineable quantities in the heavy mineral placer deposits in Sri Lanka. Sillimanite can be upgraded to alumina powder which can be used in spark plug insulators, and linings of electric furnaces (Elsner 2010). Monazite can be used to extract REEs which are considered the vitamins of material science (Dushyantha et al. 2020; Eggert et al. 2016). However, the separation of REEs from monazite could make a considerable capital cost. Consequently, the implementation of such processing plants to extract REEs cannot be recommended at this stage. Moreover, extraction of rare earth oxides (REOs) from minerals such as monazite is possible (Fig. 8), and this process would yield thorium (Th) as a by-product.

In general, the separation efficiency of the processing plant should be enhanced to reduce wastage. This is because mineral resources are nonrenewable, and the wastage during mining and processing should be minimised for maintaining a sustainable heavy mineral industry. For example, the approximate wastage of heavy minerals of the processing plant of Lanka Minerals Sands Ltd. at Pulmoddai is $\sim 8-10 \%$ which is highly disadvantageous for such value addition. 
Fig. 8 The value addition potential of Sri Lankan heavy minerals, and the identified levels of value addition (low, intermediate, or high), based on the discussion of the present study

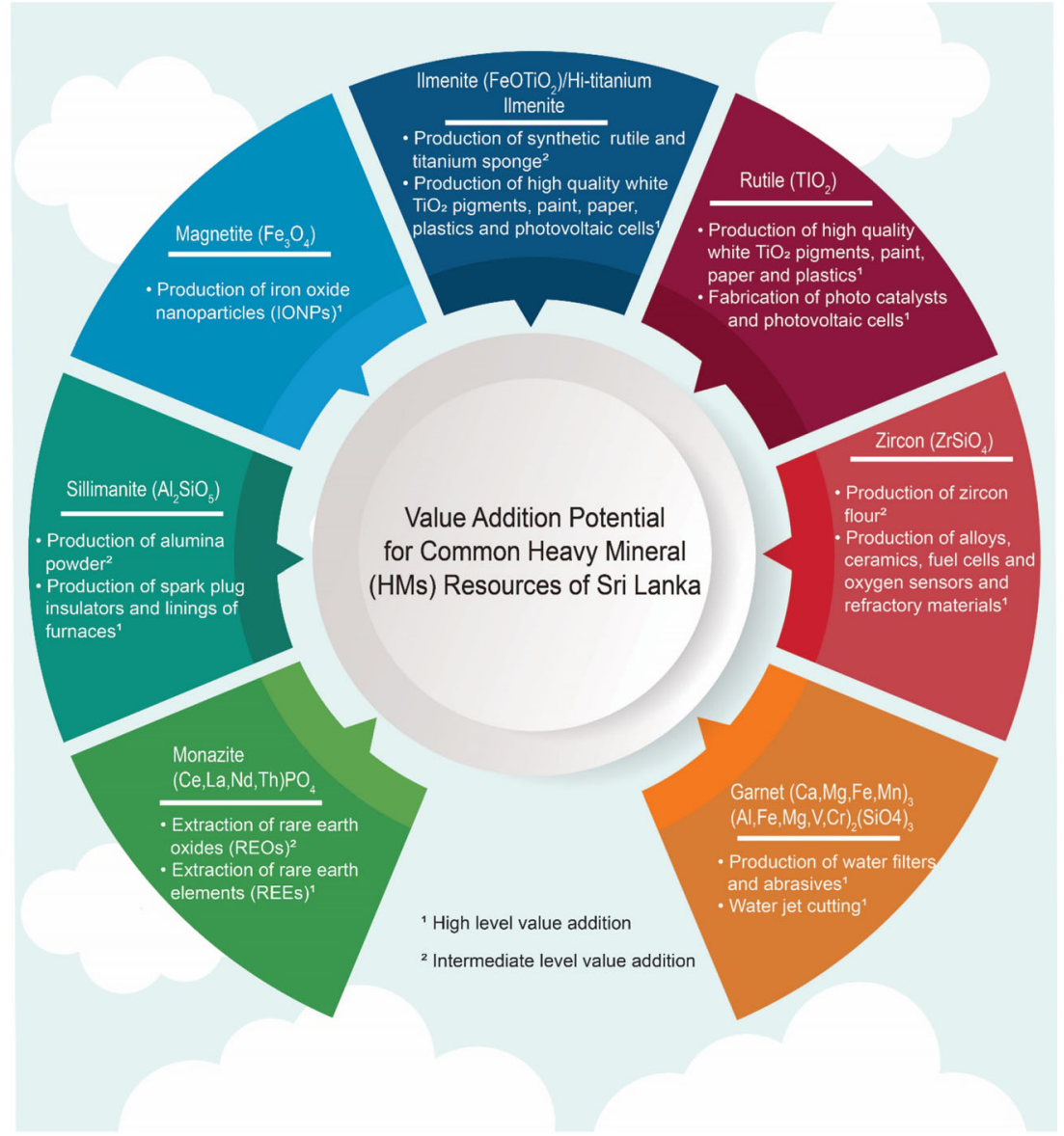

\section{Action plan to improve quality and sustainability of heavy mineral industry}

In the action plan, it is important to understand suitable levels (i.e. low, middle, and high levels) of value addition for each mineral commodity and implement all such possibilities. For example, ilmenite can be upgraded to an intermediate stage (e.g. synthetic rutile and titanium slag) which is having high market value. This would simultaneously increase the compensation to the country's economy and generate new job opportunities (Narrei and Ataee-Pour 2021). In addition, it is the responsibility of the relevant authorities to put up pilot plants to investigate the efficiency and feasibility of the value addition processes found by research (e.g. published articles, patents) at the laboratory scale. For example, Palliyaguru et al. (2017) and Wijewardhana et al. (2021) proposed methods for the production of synthetic rutile from Sri Lankan ilmenite by anion exchange (i.e. leaching iron from ilmenite using $\mathrm{HCl}$ ), and by mechanical activation and carbothermic reduction using carbonised waste coconut shells and powdered seashells as raw materials, respectively. Consequently, the initial investment in a pilot plant would be highly recommended to prove the industrial viability of the above processes. This would minimise and eventually terminate the export of heavy minerals as separated mineral sands (low-level value addition). Further, it is advisable to provide relief (e.g. reduction of royalty and providing business loans) for the private sector at the initial stage of industrial practises beyond the middle level of mineral value addition. Consequently, heavy mineral upgrading methods such as acid leaching (Mahmoud et al. 2004), sulfation (Nurdin et al. 2016), selective chlorination (Rhee and Sohn 1990), and reduction (Wijewardhana et al. 2021) would be recommended to uplift the downstream heavy mineral industry, considering challenges/limitations and opportunities in these methods (e.g. Olvera 2021).

Heavy mineral resources are nonrenewable, and thus, the available quantity is finite. Therefore, the public and private sectors should be encouraged to invest in the exploration of unidentified deposits and exploitation of already defined deposits. However, exploration and exploitation permission should be granted only for those with efficient and environmentally friendly proposals, along with environmental impact assessments (EIA) and systematic reclamation procedures. Consequently, either party should be encouraged to store the mined and separated commodities, until processing plants are ready to manufacture value-added products. In addition, the government can sign contracts or Mineral Investment Agreements (MIA) with the companies having complete 
project proposals for upgrading heavy minerals. Moreover, value-added products (end-products), intermediate products, and/or by-products can be exported, thereby increasing income to the economy of the country (Tui and Adachi 2020). Proper rules and regulations must essentially be imposed, so that any misconduct may call off the exploration and exploitation licences (Janikowska and Kulczycka 2021). Finally, it is recommended to achieve the United Nations Sustainable Development Goals (SDGs) during mining and processing of heavy mineral commodities considering (i) upgrading technology, (ii) promoting environmental education and awareness, (iii) resource utilisation, and (iv) improving quality of life (social, cultural, and economic dimensions). These actions are important to maintain a sustainable mineral industry in Sri Lanka (Fig. 9).

\section{Challenges and limitations}

There are several challenges to successfully implement a downstream heavy mineral industry in Sri Lanka. Certainly, the challenges in many developing countries can be summarised as (i) lack of sound policies/long-term action plans coupled with a strong vision and mission, (ii) lack of involvement of academia and scholars in policy and decisionmaking, (iii) lack of investors for developing end-product using HMs, (iv) competition with countries such as China for marketing intermediate value-added products, (v) the rapid increase of labour and energy costs, (vi) the ultimate production cost (i.e. the sum of power expense during mining,

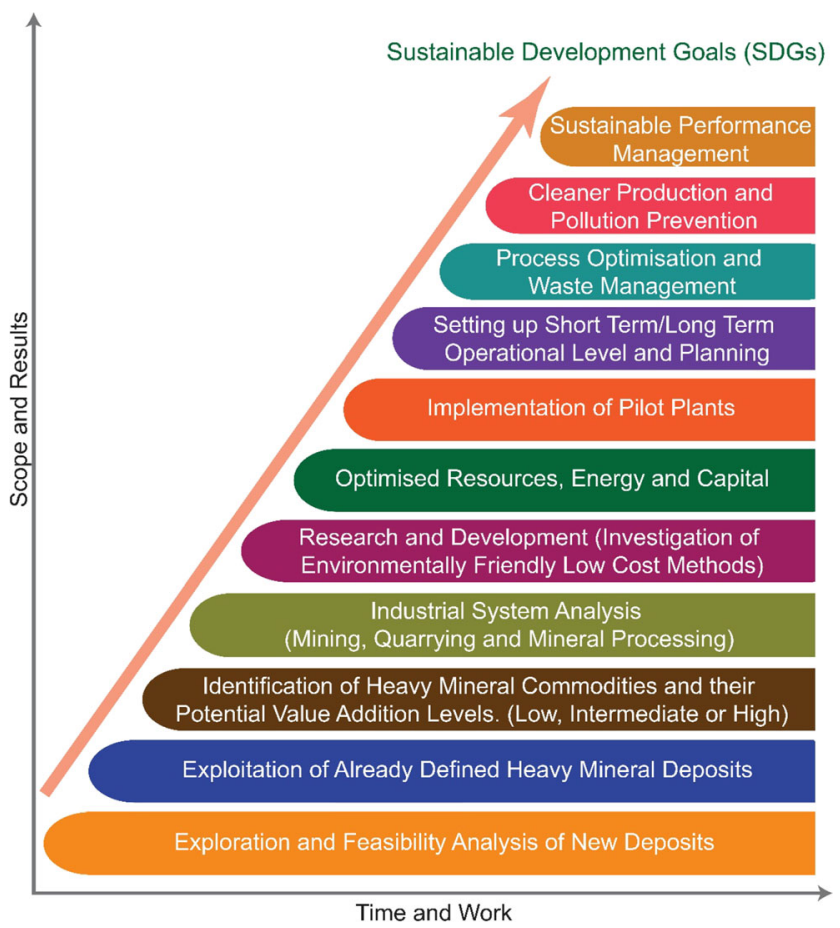

Fig. 9 The staircase of discussed concepts in the present study illustrates a successful action plan to uplift the Sri Lankan heavy mineral industry drilling and lower grade ore processing, and labour cost) may be higher than competitive countries (e.g. production cost in China is low compared to Chile), (vii) limited area for proper waste management and limited percussions for minimising greenhouse gas emissions during processing, and (viii) lack of knowledge of officials and loopholes in the law being exploited (Mudd 2010; Perks and Mudd 2020; Rodin 2015; Simpson et al. 2014). For example, Indonesia banned the export of ilmenite without upgrading, and now ilmenite is simply smuggled out or sits in big stockpiles under the effect of new rules on investment. Therefore, new job opportunities and revenue in Indonesia remain unclear (Tivey et al. 2014).

Parallel to these challenging tasks, it is worth noting that many countries/companies collect their extra production in strategic stockpiles which can be sold or used later (Perks and Mudd 2020), and thus, the world is not at $100 \%$ of utilisation rate for heavy minerals. Therefore, it is very challenging for countries like Sri Lanka to develop a downstream heavy mineral industry and compete with well-established producers. Other factors such as transportation and mining lease laws are also limiting the establishment of downstream heavy mineral industry in Sri Lanka. In addition, Sri Lanka should earn international trust to achieve good recognition in the global heavy mineral industry. However, despite certain challenges, it is worth an attempt to add value up to an endproduct at least for one heavy mineral commodity within the country. For example, local ceramic and tile manufacturers can use the available zircon in the production of opacifier which results in an end-product. Garnet sand can also be used in the production of high-quality water filters which has an escalating demand at present and most probably in the future.

\section{Conclusions}

The authors identified several potential heavy mineral placer deposits along the coastal tract of Sri Lanka. Almost all the deposits are prospects for titanium-bearing heavy minerals such as ilmenite, leucoxene, and rutile, and zirconiumbearing heavy minerals such as zircon. Moreover, most of the deposits showed enrichment of REEs compared to UCC values, and thus the abundance of highly valuable heavy minerals such as monazite. In addition, several locations along the southern beach such as Dikwella, Godawaya, Dondra, and Kirinda are prospects for garnet sand. The annual global production and unit price variations of heavy minerals show healthy growth rates, considering ilmenite as an example. In this regard, there is a timely requirement in Sri Lanka to add value (highly recommended up to an end-product) to the existing heavy mineral resources without exporting their raw form. Therefore, it is the sole responsibility of the government of Sri Lanka to impose stringent regulatory measures on raw 
heavy mineral export. Consequently, both public and private sectors must be encouraged to actively engage in heavy mineral value addition by following sustainable development goals. These would subsequently uplift the economy of the country by earning higher compensation than that earned at present.

Acknowledgements The Lanka Mineral Sands Limited is thanked for the provision of all the necessary information. The Geological Survey and Mines Bureau is acknowledged for the support extended for XRF analysis of sediment samples.

Funding This work received financial support from an Accelerating Higher Education Expansion and Development (AHEAD) Operation of the Ministry of Higher Education funded by the World Bank.

Availability of data and material Not applicable

Code availability Not applicable

Declarations Accelerating Higher Education Expansion and Development (AHEAD) Development Oriented Research (DOR) grant funded by World Bank.

Conflict of interest The authors declare no competing interests.

\section{References}

Amalan K, Ratnayake AS, Ratnayake NP, Weththasinghe SM, Dushyantha N, Lakmali N, Premasiri R (2018) Influence of nearshore sediment dynamics on the distribution of heavy mineral placer deposits in Sri Lanka. Environ Earth Sci 77:737. https://doi.org/10. 1007/s12665-018-7914-4

Condie KC (1993) Chemical composition and evolution of the upper continental crust: contrasting results from surface samples and shales. Chem Geol 104:1-37. https://doi.org/10.1016/00092541(93)90140-E

Dushyantha N, Batapola N, Ilankoon IMSK, Rohitha S, Premasiri R, Abeysinghe B, Ratnayake N, Dissanayake K (2020) The story of rare earth elements (REEs): occurrences, global distribution, genesis, geology, mineralogy and global production. Ore Geol Rev 122: 103521. https://doi.org/10.1016/j.oregeorev.2020.103521

Eggert R, Wadia C, Anderson C, Bauer D, Fields F, Meinert L, Taylor P (2016) Rare earths: market disruption, innovation, and global supply chains. Annu Rev Environ Resour 41:199-222. https://doi.org/10. 1146/annurev-environ-110615-085700

Elsner H (2010) Heavy minerals of economic importance. Germany: Bundesanstalt für Geowissenschaften und Rohstoffe (BGR). Fed Instit Geosci Nat Resources

Herath JW (1980) Mineral resources of Sri Lanka. 2nd revised edition, Economic Bulletin No. 2, Geological Survey Department, Colombo, Sri Lanka

Humphreys D (2020) Mining productivity and the fourth industrial revolution. Miner Econ 33:115-125. https://doi.org/10.1007/s13563019-00172-9

IAEA (2007) Radiation Protection and NORM Residue Management in the Zircon and Zirconia Industries.

Janikowska O, Kulczycka J (2021) Impact of minerals policy on sustainable development of mining sector - a comparative assessment of selected EU countries. Miner Econ 1-10. https://doi.org/10.1007/ s13563-021-00248-5

Jowitt SM, Mudd GM, Thompson JF (2020) Future availability of nonrenewable metal resources and the influence of environmental, social, and governance conflicts on metal production. Commun Earth Environ 1:13. https://doi.org/10.1038/s43247-020-0011-0

Mahmoud MHH, Afifi AA, Ibarhim IA (2004) Reductive leaching of ilmenite ore in hydrochloric acid for preparation of synthetic rutile. Hydrometallurgy 73:99-109. https://doi.org/10.1016/j.hydromet. 2003.08 .001

Mudd GM (2010) The environmental sustainability of mining in Australia: key mega-trends and looming constraints. Res Policy 35:98-115. https://doi.org/10.1016/j.resourpol.2009.12.001

Mudd GM (2020) Sustainable/responsible mining and ethical issues related to the Sustainable Development Goals. Geological Society, London, Special Publications 508. https://doi.org/10.1144/SP5082020-113

Muttashar HL, Ali NB, Ariffin MAM, Hussin MW (2018) Microstructures and physical properties of waste garnets as a promising construction material. Case Stud Constr Mater 8:87-96. https://doi.org/10.1016/j.cscm.2017.12.001

Narrei S, Ataee-Pour M (2021) Assessment of personal preferences concerning the social impacts of mining with choice experiment method. Miner Econ 34:39-49. https://doi.org/10.1007/s13563019-00212-4

Nguyen TH, Lee MS (2018) A review on the recovery of titanium dioxide from ilmenite ores by direct leaching technologies. Miner Process Extr Metall Rev 40:231-247. https://doi.org/10.1080/08827508. 2018.1502668

Nurdin M, Maulidiyah WAH, Abdillah N, Wibowo D (2016) Development of extraction method and characterization of $\mathrm{TiO}_{2}$ mineral from ilmenite. Int J ChemTech Res 9:483-491

Olvera BC (2021) Innovation in mining: what are the challenges and opportunities along the value chain for Latin American suppliers? Miner Econo 1-17. https://doi.org/10.1007/s13563-021-00251-w

Palliyaguru L, Arachchi NDH, Jayaweera CD, Jayaweera PM (2017) Production of synthetic rutile from ilmenite via anion-exchange. Miner Process Ext Metall 127:169-175. https://doi.org/10.1080/ 03719553.2017.1331621

Perks C, Mudd G (2019) Titanium, zirconium resources and production: a state of the art literature review. Ore Geol Rev 107:629-646. https://doi.org/10.1016/j.oregeorev.2019.02.025

Perks C, Mudd G (2020) A detailed assessment of global Zr and Ti production. Miner Econo 1-26. https://doi.org/10.1007/s13563020-00240-5

Perks C, Mudd G (2021) Soft rocks, hard rocks: the world's resources and reserves of $\mathrm{Ti}$ and $\mathrm{Zr}$ and associated critical minerals. Int Geol Rev 1-22. https://doi.org/10.1080/00206814.2021.1904294

Rhee KI, Sohn HY (1990) The selective carbochlorination of iron from titanlferous magnetite ore in a fluidized bed. Metall Mater Trans B Process Metall Mater Process Sci 21:341-347. https://doi.org/10. 1007/BF02664202

Rodin J (2015) Heavy minerals industry growth mostly influenced by China. [Online] Available: https://www.google.com/amp/s/m. miningweekly.com/article.php $\% 3$ fa_id $=361267 \&$ rep_id $=5582$. Accessed May 2021

Rudnick RL, Gao S (2005) Composition of the continental crust. In: Rudnick RL, Holland HD, Turekian KK (eds) The crust, treatise on geochemistry, vol 3. Elsevier, Oxford, pp 1-64

Simpson M, Aravena E, Deverell J (2014) The future of mining in Chile. Sydney: CSIRO Futures. [Online] Available: http://www. innovacion.gob.cl/wp-content/uploads/2014/06/The-Future-ofMining-in-Chile-WEB.pdf. Accessed May 2021

Skinner BJ, Barton JPB (1973) Genesis of mineral deposits. Annu Rev Earth Planet Sci 1:183-211. https://doi.org/10.1146/annurev.ea.01. 050173.001151 
Tivey J, Soraya N, Bellamy V, Djajadiredja (2014) Indonesia: domestic mineral processing and beneficiation in Indonesian mining sector. [Online] Available: https://www.mondaq.com/mining/327802/ domestic-mineral-processing-and-beneficiation-in-indonesianmining-sector. Accessed May 2021

Tui RNS, Adachi T (2020) An input-output approach in analysing Indonesia's mineral export policy. Miner Econ 34:1-8. https://doi. org/10.1007/s13563-020-00226-3

USGS. (2021) USGS CMG Menlo Park Fume Hood Lab-M3005A. [Online] Available: https://web.archive.org/web/20100723193900/ http://walrus.wr.usgs.gov/infobank/programs/html/facilities/mp/15. 3/m3005a.html2010. Accessed May 2021

Wijewardhana TDU, Subasinghe HCS, Ratnayake AS (2021) Value addition to ilmenite using carbonized waste coconut shells: a mechanochemical approach aided with powdered seashells as a rate raiser. Min Metall Explor 1-15. https://doi.org/10.1007/s42461-02100420-z
Zahid KM, Barbeau JDL (2010) Provenance of eastern Magallanes foreland basin sediments: heavy mineral analysis reveals Paleogene tectonic unroofing of the Fuegian Andes hinterland. Sediment Geol 229:64-74. https://doi.org/10.1016/j.sedgeo.2010.06.006

Zhang W, Zhu Z, Cheng CY (2011) A literature review of titanium metallurgical processes. Hydrometallurgy 108:177-188. https:// doi.org/10.1016/j.hydromet.2011.04.005

Zhong L, Li G, Yan W, Xia B, Feng Y, Miao L, Zhao J (2016) Using zircon $\mathrm{U}-\mathrm{Pb}$ ages to constrain the provenance and transport of heavy minerals within the north western shelf of the South China Sea. J Asian Earth Sci 134:176-190. https://doi.org/10.1016/j.jseaes.2016. 11.019

Publisher's note Springer Nature remains neutral with regard to jurisdictional claims in published maps and institutional affiliations. 